\title{
Correction to: Climate change risk to pheromone application in pest management
}

\author{
Ashraf M. El-Sayed ${ }^{1} \cdot$ Suresh Ganji ${ }^{2}$ Jürgen Gross ${ }^{3} \cdot$ Natalie Giesen $^{3} \cdot$ Margit Rid $^{3} \cdot$ Peter L. Lo $^{4} \cdot$ Anna Kokeny $^{4}$. \\ C. Rikard Unelius ${ }^{2}$
}

Published online: 15 December 2021

(c) Springer-Verlag GmbH Germany, part of Springer Nature 2021

\section{Correction to: The Science of Nature (2021) 108:47 https://doi.org/10.1007/s00114-021-01757-7}

In the original publication of this article contains error in the textbody.

1. The first sentence in the Abstract sections that reads: "Since of the first sex pheromone and the adoption of pheromone in pest management, the global pheromone market size has grown to reach USD 2.4 billion per year in 2019." should have been "Since the discovery of the first sex pheromone and the adoption of pheromone in pest management, the global pheromone market size has grown to reach USD 2.4 billion per year in 2019."

2. Figures 5 and $6 \mathrm{x}$-axes were changed "Temprature" to "Temperature".

The original article has been corrected.
Open Access This article is licensed under a Creative Commons Attribution 4.0 International License, which permits use, sharing, adaptation, distribution and reproduction in any medium or format, as long as you give appropriate credit to the original author(s) and the source, provide a link to the Creative Commons licence, and indicate if changes were made. The images or other third party material in this article are included in the article's Creative Commons licence, unless indicated otherwise in a credit line to the material. If material is not included in the article's Creative Commons licence and your intended use is not permitted by statutory regulation or exceeds the permitted use, you will need to obtain permission directly from the copyright holder. To view a copy of this licence, visit http://creativecommons.org/licenses/ by/4.0/.

Publisher's note Springer Nature remains neutral with regard to jurisdictional claims in published maps and institutional affiliations.

The original article can be found online at https://doi.org/10.1007/ s00114-021-01757-7.

Ashraf M. El-Sayed

ashraf.el-sayed@plantandfood.co.nz

1 The New Zealand Institute for Plant and Food Research Limited, Gerald Street, Lincoln 7608, New Zealand

2 Department of Chemistry and Biomedical Sciences, Faculty of Health and Life Sciences, Linnaeus University, 39231 Kalmar, Sweden

3 Federal Research Centre for Cultivated Plants, Institute for Plant Protection in Fruit Crops and Viticulture, Julius Kuhn-Institut, Schwabenheimer Str. 101, 69221 Dossenheim, Germany

4 The New Zealand Institute for Plant and Food Research Limited, Hawke's Bay, Private Bag, 1401, Havelock North 4157, New Zealand 